\title{
Housing and Its Influence on the Development of Social Inequalities in the Post-Communist Czech Republic
}

\author{
TOMÁŠ KOSTELECKÝ ${ }^{*}$ \\ Institute of Sociology, Academy of Sciences of the Czech Republic, Prague
}

\begin{abstract}
The article deals with the development of the housing market and its influence on the development of social inequalities in the post-communist Czech Republic. It originated within the framework of the project 'The Housing Market, its Regional Differentiation and Social Circumstances', sponsored by the Grant Agency of the Czech Republic. The different position of households in the housing market is understood not only as a consequence of social inequalities but also as an important source of them. The paper identifies two basic features of housing market development that have profoundly influenced social inequalities in the Czech Republic in the 1990s: the large and rapid increase of regional differences in market prices, and the division of the housing market into several sectors operating under different legal and financial conditions. Special attention is paid to the situation of households renting at market prices and the consequences of the privatisation of municipal houses.
\end{abstract}

Czech Sociological Review, 2000, Vol. 8 (No. 2: 177-193)

The study of housing has been attracting the attention of social scientists for many years. Research has predominantly focused on the failures in housing, and there have been three traditional spheres of interest: the overcrowding of flats, the poor sanitation of flats, and the lack of flats [Kemeny 1992]. In connection with post-war economic development in Western Europe and North America, interest in the first two research themes mentioned here has declined and attention has become focused predominantly on the broader socioeconomic context of housing. In 1967, Rex and Moore [1967] published the book Race, Community and Conflict, which introduced the concept of 'housing classes' into the theory. The authors, inspired by Marxist class theory, studied the functioning of the individual segments of the housing markets and the behaviour of the actors in these markets. They attempted to prove that unequal access to housing is gradually becoming a mechanism through which the ruling class tries to preserve its economic dominance. In the debate initiated on the publication of this book, the views of adherents of the 'housing classes' theory, who were from among the Marxists [e.g. Castels 1977], clashed with the views of adversaries of this theory, who were from among the neo-Weberians [e.g. Dunleavy 1981], and who saw the inequalities in the housing market as predominantly a result of the different power positions of individual social groups and influential individuals. Regardless of the attitude towards the conclusions of the work of Rex and Moore, the basic idea of their book - that inequalities in the housing market are worth studying when one is trying to understand social inequalities - has been generally accepted.

However, the relationship between housing inequalities and social inequalities in general can be seen from radically different positions. On the one hand, inequalities in

\footnotetext{
*) Direct all correspondence to Tomáš Kostelecký, Institute of Sociology, Academy of Sciences of the Czech Republic, Jilská 1, 11000 Praha 1, the Czech Republic, e-mail kostel@soc.cas.cz
} 
housing are interpreted as a 'product' of the inequalities in household incomes (the higher the income, the better the position in the housing market). On the other hand, housing inequalities can be understood as one of the sources of social inequalities. Some authors even consider, in the context of western post-industrial society, privileges in access to housing and the different position towards the individual segments of the housing market as the main factors which determine social inequalities [e.g. Saunders 1978].

It is not possible to generally decide which approach mentioned above is 'the right one', as the relationship between social inequalities and housing essentially depends on the specific situation in each society studied, and in particular the way the individual housing markets function. The situation in the post-communist Czech Republic is even more complicated by the widespread presence of status inconsistency among both individuals and households [Machonin, Tuček et al. 1996]. During communist rule, there were many people with a high level of education and a low income, and people with low employment status and a high income etc. Similarly, the mutual relation between a household's income and wealth (as measured either by the possession of valuables or the value of real estate) was typically weak under the communist regime [Večerník 1997: 106]. The same was true for the relation between household income and housing. In this article, we start with the hypothesis that inequalities in the housing market, partly inherited and partly generated by post-communist development in the Czech Republic, form one of the most important sources of social inequalities.

Before the results of the analysis will be presented it is necessary to make a short excursion into the history of housing in the Czech Republic, and to describe in brief the changes on the housing market after the fall of communism. Under the communist regime, development of housing was subject to the tight control of the state. All privately owned housing stock was nationalised (with the exception of family houses), and most new housing construction was either directly planned or strictly controlled by the state authority. Housing co-operatives fell under the state administration, rents were subject to state regulation, market prices in housing were abolished and substituted with 'administrative' prices. From the legal point of view, four statuses with regard to housing were dominant. There were state-owned blocks of flats, blocks of flats owned by different (state) companies, co-operative blocks of flats, and privately owned family homes. The state flats used to be assigned to applicants from a waiting list, and the company flats were assigned to company employees. Residents of both state and company flats had neither ownership rights nor duties, but they had a 'decree' claiming their right to stay in the flat as tenants for an 'unlimited time', and furthermore, they had automatic right to transfer the 'decree rights' to their children. Both state and company flats were provided to applicants for free on the basis of need and availability. Usually the rents did not even cover the maintenance costs. Given for free (if corruption practices are not taken into account), the state and company flats had officially a zero market price. Due to the longterm housing shortage, however, 'possession of a decree' itself has become tradable property, and many ways, both the semi-legal and illegal 'sale or purchase of' a state or company flat (that is a decree) have developed over time.

Co-operative housing, which had even a pre-communist tradition in the Czech lands, was based on the idea of 'collective self-help' of the members of housing cooperatives. Each citizen could become a member of one of the co-operatives by paying a membership fee. Although the construction of co-operative houses was partly subsidised by the state, residents of co-operative houses had to cover a substantial part of construc178 
tion costs (in some cases simply by paying the money, in other cases through unpaid work during the construction of the houses). The rents paid by tenants in co-operative flats had to fully cover the maintenance costs, and also included the repayment of state loans. It was legally possible to buy membership in the co-operative, and thus to gain the right to use a co-operative flat. In reality, the real prices in such deals greatly exceeded the membership fees, since they included an unofficial 'bonus' calculated on market principles of supply and demand.

The last legal status on the housing market during communism was represented by privately owned family houses, in which the residents were also the owners. Although this sector was formerly considered to be only a residue of the pre-communist period, as the incapability of the state to fulfil people's housing needs was more evident, the regime cautiously allowed people to built their own houses. Later, self-construction of family houses was even partially supported through cheaper loans or subsidies. Despite this fact, however, the owners of family houses had to finance the construction (either mostly or completely) and pay all maintenance costs. It was possible to buy or sell a house for an official 'valuation price', but in practice market prices were used, including an unofficial extra bonus.

Since the fall of the communist regime, several important changes in the field of housing have been observable. The termination of state-financed housing construction, combined with the decrease in real wages, brought about a deep decline in housing construction after 1991. This fact is evident from the figures showing the number of apartment constructions initiated, which was typically in between 55 and 60 thousand annually up until 1990, and which dropped to only 10,899 in 1991, 8429 in 1992 and even to 7454 in 1993 [for detailed information see Andrle 1994 and Andrle and Vlášek 1998]. At the same time, the rapid development of new private companies highly increased the pressure to change flats into offices and, especially in the most attractive cities, like Prague or Karlovy Vary, a considerable number of foreigners entered into the demand side of local housing markets. All this, together with the increasing need of housing for newly emerging families founded by young people born during the population boom in the 1970s, resulted in a sharp increase in prices.

Although some changes on the housing market affected everybody, some development was specific to individual sectors of the housing market. Many state-owned blocks of flats have been returned to the previous owners or their descendants, while the majority of the remainder has been transferred from state to municipal ownership. An overwhelming majority of company houses have been sold to private owners in the process of privatisation, together with factories. Thus the sectors of private and municipal rental houses have come into existence, while company-owned housing has practically ceased to exist, and the scope of state-owned housing has been substantially reduced. Later, some municipal houses were sold to companies or co-operatives made up of tenants, or individual flats were sold directly to tenants. However, despite the substantial shifts in the ownership structure and the many changes to legislature, the basic principles of the housing market functioning in post-communist Czech Republic remain rather similar to those used in the communist period. In an effort to maintain social peace and to help families to survive the first phases of economic reforms, the government has decided to maintain the system of state regulation of rents, not only in municipal flats but also in houses returned to their former owners. Thus the change of ownership did not affect the status of tenants living in the flats at the time of the change in ownership, as far as the 
rent they have to pay is concerned. Consequently, the 'possession of a decree' has remained transferable to family members, exchangeable with some other 'owner of a decree' and, of course, tradable on the black market. In addition to the above mentioned sector of the rental housing market which has remained under careful state control, a quite new sector of rental housing based on free market principles has been gradually developing. The legislature allowed for setting up market rents if the tenant was not a citizen of the Czech Republic, if the flat had been vacant prior to renting (this does not apply to the exchange of flats) or if a privately owned family house was being rented. Moreover, due to the fact that there was basically no price regulation on sublease contracts, a growing number of people had the status of 'subtenants' and paid a market rent while living in flats of various ownership types.

\section{Methodological Remarks}

The methodology of the research follows the idea that the key information necessary for understanding the role housing plays in the development of social inequalities in the postcommunist Czech Republic is information about prices. That is why the data from general statistics, even census data, could not be a main source of information, as official housing statistics focus on the physical aspect of housing (the size of the flats, technical standards...). Therefore, we have decided to conduct our own field research to search for relevant information about the market prices of both rents and purchases. A network of co-operators from among university students was set up to cover all regions in the Czech Republic. We decided not to depend on the only source of information on prices in the housing market. On the contrary, we have tried to avoid any systematic bias by using diversified sources. Thus our basic source of information was of two types: newspaper advertisements and information collected and posted by local real estate companies. As far as advertisements in the press are concerned, a total of 23 different titles were observed. Four of them (Mladá Fronta Dnes, Lidové noviny, Hospodárské noviny and Zemédělské noviny) were national newspapers, and another eleven newspapers were the most relevant regional ones. The bulk of information, however, came from specialised 'advertisement newspapers', of which three titles (Annonce, Inzert Express, Inzertspoj) have a dominant position in this respect. Most such advertisement newspapers use the same system of financing - the companies gain their income from those who buy the newspaper but not from those who advertise. From the point of view of our research, the particular advantage of this system lies in the easy access of potential advertisers to the newspaper and consequently the vast number of advertisements being published. The main disadvantage is the easy possibility of multiple advertising, and therefore the need for careful control of the data and the subsequent replacement of duplicated advertisements. Data from all kinds of newspapers was collected every week for a period of six months. As for real estate companies, we identified several of the largest ones in each region (avoiding those mutually interconnected and thus presenting the same offers), and then we collected information on a month-to-month basis, also for a period of six months (September 1996-February 1997).

Several different types of data have been obtained. We distinguished flats and family houses, renting and sales, and supply and demand. Each of the particular data sets has a similar structure, which includes as many of the following as available: flat or house; locality (municipality and district); number of rooms; floor space $\left(\mathrm{m}^{2}\right)$; legal status of the flat (house); purchase price (or monthly rent); the source of information (newspaper ad- 
vertisement or real estate company); month in which data were collected. In spite of the fact that the 'offers' in newspaper advertisements or real estate agencies are generally more specific than the 'demands' (and consequently files with data about flats or houses on offer contain more information), it seems useful to maintain the same structure for both types of files. It allows for merging files for some specific purposes, such as analysing price levels (we believe that real prices lie somewhere between the prices asked by owners and the prices offered by buyers/tenants).

The problem of the representativeness of the obtained data must also be mentioned here. Theoretically, the best option would be to collect all information about both supply and demand on the respective housing markets available to the public, that is to record all individual advertisements in the newspapers as well as all offers made public by the real estate agencies in the respective regions. It is clear, however, that this goal is unrealistic at least due to the limited financial resources and capacity of the research team. But the problem is that even the use of probability sampling is not possible, because there are many published advertisements containing either no or only a little specific information. To give an example, advertisements with texts such as 'We want to buy a flat. Good price.' or 'Large co-operative flat for sale. Price negotiable.' are generally not usable. That is why we have concentrated on recording advertisements that contained as much relevant information as possible. Therefore, strictly speaking, our data cannot be considered a statistically representative set describing 'the complete supply and demand presented in newspaper advertisements and by real estate agencies'. Instead the data we have collected form a probability sample of those offers from newspaper advertisements and real estate agencies which contain enough specific information to be recorded. The character of the data should be taken into account as the sampling error cannot be calculated accurately. However, it should be noted that there is no way in which to obtain a data set that can be regarded as strictly representative from the statistical point of view. Moreover, the methods of the analysis of the data we have used in the article were not sensitive to sampling errors, and thus the results presented below are robust. Altogether, more than 22,000 cases were collected. After the exclusion of duplicated records and logical control, 21,688 cases remained (6503 records concerning rental housing, 8240 records concerning flat purchases and 6945 records concerning family house purchases). As all recorded data include information about the location of the estate (municipality, district, region) and the data from all 76 districts + Prague were collected, several different regional sortings could be carried out. The number of recorded cases were roughly proportional to the number of flats and houses in each particular region, with three exceptions: Prague and the North Moravian districts were over-represented in the data set, while districts in South Moravia were under-represented. In most analysis working with regional sub-samples, the division of the Czech Republic into 13 regions + Prague as a separate spatial unit was used, and in some cases a division into 76 districts + Prague was used. The regions correspond to the administrative regions of the Czech Republic introduced in autumn 1997, while the districts correspond to administrative districts in effect from 1997.

We then focused on the group that is the most threatened by housing problems newly-founded families [Matyás 1994]. A short questionnaire was prepared in order to determine basic data on the social and economic structure of newly-founded families, their housing situation at the time of their marriage, and their strategy for the future. Data was collected for a period of six months (June 1997-November 1997) with the assistance of clerks in selected register offices (The register office is where anyone wishing to be 
married is obliged to fill in statistical forms necessary for the official registration of the marriage.). The sample of register offices covered all regions as well as all types of municipalities. Every couple appearing at the selected register offices who met the selection criteria (age of both under 35 years, first marriage for both) was asked to fill the questionnaire - brides and bridegrooms separately. In the end a total of 1966 completed questionnaires were gathered, representing around $7 \%$ of the couples married during that time period throughout the entire country.

\section{Social Inequalities Generated by the Housing Market}

One of the characteristic features of the transformation of post-communist societies is the increase of inequalities among individuals, households, social groups, and territorially defined units - towns, districts, regions [Večerník 1992, 1997; Matějů 1993; Machonin, Tuček et al. 1996; Kostelecký 1994, 1995]. The inequalities mentioned above have various causes, manifold features and different consequences. It is important to note, however, that some are 'generated directly' while others are partially influenced by the position of particular individuals or households in the housing market. In the search for characteristics of the housing market which have an influence on social inequalities, several such attributes can be identified. The first one is the division of the housing market into regional and local markets that function to some extent autonomously [Kemeny 1992]. The second concerns the division of the housing market into segments which may operate under different rules [Siksiö and Borgegard 1990]. The division into different segments also relates to the differences between the housing situation of 'old' households, which already lived in their flats or houses (either owned or rented) before the breakdown of communist rule, and new households, which have entered the housing market under new conditions, after the regime had changed.

\section{Regional inequalities}

The fact that there are substantial differences among various regions, cities and neighbourhoods in respect to both the prices and the quality of housing is no surprise to anyone who lives in a country with a market economy. However, under the communists in the Czech Republic, planners intentionally diminished all types of regional differences, including those concerning housing. The idea of regional equality and strict control over the trade in real estate, combined with the authority of state administration over regional development, resulted in a situation radically different from that in most Western countries. The overwhelming majority of state money intended for new housing went to district authorities, and consequently to the construction of blocks of flats in the district capitals (75 middle sized cities spread throughout the country). This housing policy more or less ignored smaller towns and villages, but at the same time suppressed the development of the biggest cities and metropolitan areas. The only exception from this rule was the strongly supported housing construction in 'old industrial areas' which had been founded on the coal mining, steel and chemical industries. Therefore, at the end of communist rule, the country inherited a settlement structure for which the following features were typical: no large metropolitan areas, limited sub-urbanisation, housing stock of a similar type and technical standard throughout all regions, little regional difference in the purchase price of flats, houses and land, and virtually no regional differences in rents. 
The partial introduction of free-market principles into the housing sector at the beginning of the economic transformation revealed huge differences among the regions (see Table 1).

Table 1. Regional differences in the prices of flats (per $1 \mathrm{~m}^{2}$ of living space) in 1996 - figures show the distribution of flats (in \%) into price categories based on quintiles calculated on the country level

\begin{tabular}{lrrrrr} 
Regions & 1. quintile & 2. quintile & 3. quintile & 4. quintile & 5. quintile \\
\hline Praha & 0.4 & 2.9 & 4.0 & 7.9 & 84.8 \\
Central Bohemia & 1.2 & 18.3 & 23.8 & 40.4 & 16.3 \\
České Budějovice & 12.1 & 29.5 & 26.8 & 19.7 & 11.8 \\
Plzeň & 2.8 & 14.1 & 25.4 & 37.8 & 19.9 \\
Karlovy Vary & 8.0 & 30.4 & 27.5 & 20.3 & 13.8 \\
Ústí nad Labem & 89.2 & 9.8 & 0.9 & 0.0 & 0.2 \\
Liberec & 22.6 & 25.6 & 32.3 & 13.1 & 6.4 \\
Hradec Králové & 20.2 & 29.3 & 12.1 & 12.1 & 26.3 \\
Pardubice & 2.4 & 11.8 & 23.6 & 38.7 & 23.5 \\
Jihlava & 6.9 & 27.5 & 25.5 & 32.4 & 7.8 \\
Brno & 2.6 & 11.8 & 23.7 & 34.6 & 27.2 \\
Olomouc & 5.3 & 29.7 & 36.6 & 26.3 & 2.0 \\
Ostrava & 55.8 & 31.1 & 8.8 & 2.6 & 1.7 \\
Zlín & 3.4 & 12.1 & 20.9 & 36.9 & 26.7 \\
The Czech Republic & 20.0 & 20.0 & 20.0 & 20.0 & 20.0 \\
\hline Source: & & & & & \\
\hline
\end{tabular}

Source: [Šetrení... 1996].

The figures in Table 1 illustrate well the extent of price inequalities among different regional housing markets. While in the entire sample $20 \%$ of the most expensive flats belong to the fifth quintile, in Prague almost $85 \%$ of flats belong to this category, and only $0.4 \%$ of flats fit in the first - the cheapest - quintile. On the contrary, almost $90 \%$ of flats in the industrial region of Ústí nad Labem in North-Western Bohemia belong to the cheapest quintile, while there are practically no flats in the two most upper quintiles. An even higher level of price inequality among the regions was revealed when the prices of family houses were compared. Differences in market rents were slightly lower.

It is important to mention that the 'market evaluation' of the housing in different regions does not simply trace inequalities in household incomes. It also includes the situation in the local labour market, perspectives of local economy, the traffic infrastructure, environmental conditions, the attractiveness of the region for foreigners, the positive or negative image of the place etc. In fact, the extent of price inequalities in different regional housing markets highly exceeded that of household incomes, which were surprisingly low (see Table 2). 
Table 2. Regional differences in household incomes in 1996 - figures show the distribution of households (in \%) into categories based on quintiles calculated on the country level

\begin{tabular}{lccccc} 
Regions & 1. quintile & 2. quintile & 3. quintile & 4. quintile & 5. quintile \\
\hline Praha & 19.5 & 16.8 & 17.3 & 18.3 & 28.1 \\
Central Bohemia & 20.1 & 21.0 & 18.6 & 20.6 & 19.7 \\
České Budéjovice & 18.3 & 20.5 & 21.2 & 20.7 & 19.3 \\
Plzeň & 19.9 & 20.1 & 20.9 & 20.0 & 19.7 \\
Karlovy Vary & 23.1 & 21.9 & 19.1 & 20.5 & 15.4 \\
Ústi nad Labem & 22.8 & 20.6 & 20.5 & 18.3 & 17.8 \\
Liberec & 22.5 & 19.4 & 19.2 & 20.6 & 18.3 \\
Hradec Králové & 17.8 & 23.2 & 20.0 & 18.9 & 20.1 \\
Pardubice & 19.3 & 20.7 & 22.8 & 20.7 & 16.5 \\
Jihlava & 18.0 & 20.9 & 20.9 & 21.1 & 19.1 \\
Brno & 19.5 & 19.5 & 19.2 & 21.0 & 20.8 \\
Olomouc & 18.8 & 20.9 & 22.2 & 21.4 & 16.7 \\
Ostrava & 20.9 & 20.7 & 21.5 & 20.0 & 16.9 \\
Zlín & 19.8 & 18.0 & 20.2 & 20.2 & 21.8 \\
The Czech Republic & 20.0 & 20.0 & 20.0 & 20.0 & 20.0 \\
\hline Source & & & & & \\
\hline
\end{tabular}

Source: [Šetření... 1996, Př́rimový... 1998].

The fact that a high level of regional inequality in the prices of housing contrasts with the relatively similar income structure of the households in individual regions has two opposite consequences for the development of social inequalities. For those living in attractive regions, and who owned some real estate or co-operative flat, the rapid price growth in such areas meant high capital gains, and consequently an increase in the property value, both of which have nothing to do with the household members' success or failure in the labour market. Conversely, those living in less favourable regions were suffering a relative loss. It should be stressed here that the capital gains mentioned above were high in comparison with household incomes. The average price of a one-bedroom flat of $57 \mathrm{~m}^{2}$ of living space in Prague in $1996(1,019,331 \mathrm{CZK})$ represented 6.2th multiple of the annual net income of the average Czech household at that time, while the price of the same flat in the 'cheapest district', the city of Most in North-Western Bohemia, (154,755 CZK) was slightly less than what the average Czech household earned in one year. Similarly, the price of 'tenants' decrees' as well as market rents in attractive regions became much higher than those in less attractive areas (even if controlled for regional differences in incomes). All this made moving from 'cheap' regions to 'expensive' ones more difficult than any time before. This can be well documented through statistical figures on migration which show that all of the most expensive districts (Prague, Brno, Plzenn, Zlín...) were losing their populations in spite of the high number of available jobs and the lowest rates of unemployment (for example $0.4 \%$ in Prague). The lowest prices in the housing market were typical for regions with the highest rate of unemployment [Heřmanová and Kostelecký 2000]: the highest unemployment rate was in the district of Most in 1996 $(9.4 \%)$, which had the lowest prices for flats. To live in such 'low-price regions' could be risky: anyone who lost their job (and the probability of losing one's job was the highest in these regions) found themselves in a kind of a 'social trap'. To find a new job in the region in which one lived was difficult due to the high unemployment rate, while to move 
to some region with more jobs was difficult because of the cost of housing there. When pressed to choose between two 'bad options' - to stay at home on social benefits or to reduce one's own housing standard while moving to regions with available jobs - most households elect to maintain their housing standard and not to move.

The unequal real estate price increase has, of course, quite an inverse impact on the households that were established only once the new situation in the housing market was in effect. Thus the most serious problems with access to housing are felt by new households in the regions with the highest prices in housing in relation to the level of local income. While not taking into account the possibility that new households received help from relatives, the easiest way for a new household to obtain its own housing was to rent a flat on the free market. The following table will illustrate the range of regional differences in access to housing by displaying ten districts with the easiest and ten districts with the most difficult access to housing on the free market.

Table 3. Regional differences in access to housing on the free market in $1996-$ figures show the number of $\mathrm{m}^{2}$ of living space which a local household with an average local income could afford to rent on the free market if paying $30 \%$ of its income on housing

\begin{tabular}{lclc}
$\begin{array}{l}\text { Districts with } \\
\text { the easiest access }\end{array}$ & $\begin{array}{c}\mathrm{m}^{2} \text { of living } \\
\text { space }\end{array}$ & $\begin{array}{l}\text { Districts with the } \\
\text { most difficult access }\end{array}$ & $\begin{array}{c}\mathrm{m}^{2} \text { of living } \\
\text { space }\end{array}$ \\
\hline Litoměřice & 80 & Capital Prague & 23 \\
Jeseník & 79 & Prague-East & 30 \\
Karviná & 78 & Plzeň-South & 31 \\
Hodonín & 77 & Prague-West & 33 \\
Nový Jičín & 77 & Brno-Countryside* & 34 \\
Chomutov & 72 & Brno-City & 36 \\
Přrov & 71 & Karlovy Vary & 37 \\
Most & 71 & Cheb & 41 \\
Frýdek-Místek & 66 & Benešov & 41 \\
Bruntál & 66 & Náchod & 41 \\
\hline
\end{tabular}

*) Subject to high sampling error due to the low numbers of registered cases Source: [ [Šetření... 1996, Přijmový... 1998].

It is clear from the table that regional differences in access to housing on the free market are high. On one side of the scale there are districts with a rather favourable marketrent/income ratio, allowing new local households with average incomes to rent a smaller or larger two-bedroom flat (from 66 to $80 \mathrm{~m}^{2}$ ) on the free market, while not spending all their money on housing. On the other side there are regions where new local households, paying the same share of their average income on housing, could hardly rent more than a studio with - or even without - a kitchen of merely $30-40 \mathrm{~m}^{2}$; in Prague the area was only $23 \mathrm{~m}^{2}$.

The fact that difficulties in the search for separate housing for new households depend on the housing market situation in particular regions is documented by the results of a survey conducted among couples at the time of their marriage. As the number of questionnaires $(\mathrm{N}=1966)$ received did not allow for working with too many regionally defined sub-samples, we divided the questionnaires into three groups, defined by three different levels of the accessibility of housing measured by prices in housing / local in- 
comes ratio, and then statistically tested for whether the respondent's answers depend on the housing situation in the regions where they live. As the answers of brides and bridegrooms in regard to housing were rather similar, and moreover, as the overwhelming majority of them lived either together or in the same type of region prior to marriage, we will present only the answers of the bridegrooms (presented are only answers with statistically significant differences at $\mathrm{p}<0.01$ ). It is evident from the data that the greater the problems with access to housing were, the greater the role of the extended family also was. In regions with the most difficult access to housing, $46.2 \%$ of respondents claim that "problems with housing will be solved with the help of the extended family", while only $38.7 \%$ did so in 'average' regions, and $32.6 \%$ in the regions with relatively the easiest access to housing. 'Help from the extended family' can take various forms: $12.6 \%$ of respondents living in regions with extensive housing problems wanted to borrow money from relatives, while only $7.4 \%$ of respondents living in regions with the easiest access to housing planned to do so. More often, help from the extended family simply means that a new family does not constitute a new household, but starts or continues to live with parents. While in regions with the easiest access to housing $14.9 \%$ of new couples live together with the parents of either the bride or bridegroom, in areas with the greatest difficulty in access to housing the figure is $23.9 \%$. Finally, it is not very surprising that the level of satisfaction with one's own housing also depends on the situation in the local housing market. While $42 \%$ of couples in 'regions with the least problems' were satisfied with their housing, the same was true for only $33.5 \%$ of couples living in the 'regions with the greatest problems'.

\section{Inequalities connected with the division of the housing market into segments}

The evolution of the housing market after the fall of communism resulted in the establishment of distinct segments which operate under different rules. Segments are defined both by the type of ownership and by how the housing expenditures (rent) are determined. It is possible distinguish five segments:

a) Private flats and family houses occupied by owners

b) Co-operative flats occupied by members of co-operatives

c) Rental flats in public (municipal or state) ownership with regulated rents

d) Rental flats in private ownership with regulated rents

e) Rental flats of any ownership with market rents.

The position of the household in a certain segment of the housing market influences three important things: the household property value, the structure of household expenditures (namely the share of housing expenditures) and how easy or difficult the household can alter its own position in the housing market. As far as household property value is concerned, it is clear that the differences are huge. On one side of the scale there are households that own the flat or house in which they live, which of course represents the bulk of their total property. Households living in co-operative flats can sell their membership in the co-operative and, similarly to those living in rental flats with regulated rents, can (legally, semi-legally or illegally) capitalise their tenant rights (specifically the possibility to pay less than the market rent). On the other side, households that live in rental flats with market rents cannot gain any money from selling 'their housing', as they possess neither real estate nor any tradable 'tenant rights'. The following table shows the average cost of the flat in different market segments by regions. 
Table 4. Price differences between flats of different ownership status in 1996 by regions (family houses not included) - figures show the average purchase price per $1 \mathrm{~m}^{2}$ in CZK and private/rental flats price ratio in $\%$ by region

\begin{tabular}{lrccc} 
Region & \multicolumn{3}{c}{ Flats } & $\begin{array}{c}\text { (Private/Rental) } \\
\times 100 \%\end{array}$ \\
\hline Praha & Private & Co-operative & Rental $^{* *}$ & 213 \\
Central Bohemia & 81,240 & 16,974 & 9,972 & 136 \\
České Budějovice & 7,722 & 8,796 & 6,402 & $112^{*}$ \\
Plzeň & 10,362 & 7,387 & $6,572^{*}$ & 173 \\
Karlovy Vary & 9,191 & 7,221 & $4,202^{*}$ & $219^{*}$ \\
Ústí nad Labem & 4,245 & 3,217 & 1,689 & 251 \\
Liberec & 8,277 & 6,731 & 3,932 & 211 \\
Hradec Králové & 9,463 & 8,104 & 4,590 & 206 \\
Pardubice & 9,090 & 8,967 & 7,826 & 116 \\
Jihlava & 8,424 & 7,853 & $8,383^{*}$ & $100^{*}$ \\
Brno & 11,380 & 9,226 & 6,400 & 178 \\
Olomouc & 8,862 & 8,060 & $4,891^{*}$ & $181^{*}$ \\
Ostrava & 7,157 & 4,153 & 3,714 & 193 \\
Zlín & 9,387 & 9,018 & $8,754^{*}$ & $107^{*}$ \\
\hline
\end{tabular}

*) Subject to high sampling error due to low frequencies in respective sub-categories. **) Category 'Rental flats' here refers to flats with regulated rents (state, municipal or owned by private landlord)

Source: [Šetrení... 1996].

In spite of remarkable regional differences, it is worth noting that the same logic is revealed by the data from all regions. The most expensive are private flats, but the prices of co-operative flats are not much lower. The gap lies between co-operative and rental flats: the number of co-operative flats offered or demanded on the market is much higher than the number of rental flats and, even more important, their average purchase price is also substantially higher in most regions. Thus the diversified price increase of housing in the post-communist period favoured households living in privately owned flats and cooperative flats, while households living in rental flats were at a disadvantage. Moreover, the large discrepancy between the 'property value' of flats of different ownership categories represents an important obstacle for households living in rental flats to move to another flat of the same size. Its choice must either be limited only to other rental flats or to paying a considerable amount of money when moving is necessary.

In the post-communist era, however, there were two possible mechanisms for enabling a household to change their position in the housing market without moving from the flat it was living in: restitution and housing privatisation. Both of these procedures have their own winners and losers. In both cases, who the winner or the loser was has nothing or very little to do with household incomes or the success or failure of the individual household members in the labour market. For households living in state-owned flats that were returned to the former owners or their descendants, this change has some important consequences. Although rents remained controlled (and as a result housing expenditure does not differ from that of households living in public rental flats), the position of the household in the housing market became considerably worse, even when we assume that all landlord-tenant relations were correct, and both sides followed the laws and regula- 
tions. The danger emerged that a landlord might want to have the flat vacated and then use it for himself, members of his family, or rent it as an office at market prices. In spite of the fact that in this situation the landlord was required to provide tenants with a substitute flat of adequate quality, moving to a substitute flat could mean a worsening of the housing standard of tenants, particularly as far as the location of the flat is concerned. To become a tenant in a privately owned flat even further reduced the number of options if such a household decided to move. The only legal, and the most frequently used, possibility for moving while maintaining the 'right to regulated rent' is the exchange of a flat with another household. ${ }^{1}$ As an overwhelming majority of households living in state or municipal owned flats, not to mention people living in co-operative flats, are reluctant to move to rental flats with a private landlord, only other flats with private landlords can be considered. The third, and most important, fact is that households which found themselves in the position of tenants in privately owned houses lost the chance to privatise the flats they were living in.

This leads us to the second process in the housing market which could have a remarkable influence on the household position within the social structure - the privatisation of municipal and state owned flats. There were many ways in which to privatise flats in public ownership, but despite the proper technique of privatisation, in the majority of cases the flats ended up in the hands of tenants. As the declared, prime objective of privatisation was to remove the financial burden of maintaining housing stock from the municipalities and to shift it to the future private owners, taking into account the low level of purchasing power of most households, municipalities sold the flats well below market price. In Prague, for example, flats were sold to tenants for about $2000 \mathrm{CZK}$ per $\mathrm{m}^{2}$, and in smaller cities it was usually less. Commonly, only part of the total amount had to be paid immediately, while the rest could be paid later in instalments. Moreover, this arrangement allowed some municipalities to let new owners deduct money they would spend on repairs and reconstruction from the purchase price. Regardless of whether the purchase price was high or low when compared with incomes and savings of the tenants, to sell flats for below-market prices means nothing less than capital gain being donated to new owners by the other taxpayers. The amount of the 'granted money' varies, depending on purchase price, the size of the flat, its quality and location. The capital gain of households having purchased an average, quality, two-bedroom flat, $77 \mathrm{~m}^{2}$ in area, for 2000 CZK per $\mathrm{m}^{2}$, ranges between 0 and 230,000 CZK (if the average 'price of a decree' in the region is subtracted from the total gains). If the purchase price considered is $1000 \mathrm{CZK}$ per $\mathrm{m}^{2}$, capital gains increase to about 20,000 to $300,000 \mathrm{CZK}$ per household. In Prague, however, the figures are much higher: 710,000 and 790,000 CZK respectively. Even if the purchase price in Prague was set up to $3000 \mathrm{CZK}$, the capital gain was still over $630,000 \mathrm{CZK}$, which represents a 3.3 multiple of the annual income of the average Prague family. How huge an amount of granted money that $630,000 \mathrm{CZK}$ represents will be even clearer from the next example. Suppose that two average households are living in two identical $77 \mathrm{~m}^{2}$ flats in the same location, but in two different municipal houses. Flats in the first house are offered to tenants for $3000 \mathrm{CZK}$ per $\mathrm{m}^{2}$, while the other house remains in public ownership. As a result the 'lucky' household in the first flat becomes the

1) The exchange of flats itself is difficult, as the pairs of households interested in each other's flats must first be found. Then a 'contract on the exchange of flats' must be agreed to by the owners of both flats. 
owner of the flat with a price on the market highly exceeding the market price of its less lucky neighbour's flat. If the less lucky household were to decide to buy the same flat on the free market, it would have to borrow 630,000 CZK from either the building savings bank or a mortgage bank. Monthly payment of the loan would be $8820 \mathrm{CZK}^{2}$ in the case of a loan from a building savings bank, and $7647 \mathrm{CZK}^{3}$ in the case of a mortgage bank, which would represent $54 \%$ (47\%) of the total income of an average household. In practice, however, this less lucky family might not get either of the loans mentioned, as the average household income may not be enough to qualify for such loans. ${ }^{4}$

Thus far all that has been said about the inequalities generated by the division of the housing market into different sectors has left aside the households living in rental flats with market rents. Such households are in the worst position, as they not only have nothing to capitalise, but their housing expenditures could also be substantially higher than the average for the population. As Vajdová and Buštíková [1998] show, these households do not substantially differ from the average Czech household in any characteristic, except that of the age of the household members. In fact, the key characteristic is that these are new households, established under the new conditions of the housing market. There are several possible ways by which newly established households can get their own, separate housing: they may receive or inherit some sort of housing from parents or relatives; they may buy or build some flat or house; or they may rent it out of the free market. Although the last option is open to everyone, including those without any property, the 'dark side' of this possibility is the necessity of paying market rent. This may cause considerably higher housing expenditures for these households than for those living in flats with regulated rent (see next table).

2) Under the following conditions: the family already saved another 630,000 CZK and has it in its account for down payment, the monthly payment is set up to $0.14 \%$ of borrowed $630,000 \mathrm{CZK}$, the loan is to be paid back within 10 years, the state subsidy applied, no tax deductions applied.

3) Under the following conditions: the family already has 270,000 CZK for down payment, the interest rate is $14 \%$, the loan is to be paid back within 20 years, no state subsidy and no tax deductions applied.

${ }^{4}$ ) It depends on the number of family members and their age, as banks take into account the minimum standard of living of the applicant's family. While the average income of a family without children would qualify, that of a family with two children would definitely not. 
Table 5. Housing expenditures ${ }^{*}$ in flats with market rent, in flats with regulated ${ }^{* *}$ rent and in flats bought on loan ${ }^{* * *}$ and their relation to incomes of an average local household living in $77 \mathrm{~m}^{2}$ flat in January 1st 1997 by region

\begin{tabular}{lcccccc} 
& \multicolumn{3}{c}{ Housing expenditures $(\mathrm{CZK} / \mathrm{m} 2)$} & \multicolumn{3}{c}{ Housing expenditures/Total income (\%) } \\
Region & Free market & Regulated & On loan & Free market & Regulated & On loan \\
\hline Praha & 193 & 32 & 135 & 91 & 15 & 64 \\
Central Bohemia & 99 & 28 & 81 & 54 & 15 & 44 \\
České Budějovice & 90 & 30 & 72 & 49 & 16 & 39 \\
Plzeň & 96 & 30 & 82 & 53 & 16 & 45 \\
Karlovy Vary & 94 & 28 & 74 & 56 & 17 & 44 \\
Ústi nad Labem & 66 & 30 & 43 & 37 & 17 & 24 \\
Liberec & 87 & 30 & 69 & 50 & 17 & 39 \\
Hradec Králové & 92 & 28 & 79 & 50 & 15 & 43 \\
Pardubice & 75 & 28 & 83 & 43 & 16 & 48 \\
Jihlava & 75 & 28 & 76 & 42 & 15 & 42 \\
Brno & 99 & 30 & 86 & 54 & 16 & 47 \\
Olomouc & 67 & 30 & 76 & 38 & 17 & 44 \\
Ostrava & 57 & 30 & 51 & 33 & 17 & 30 \\
Zlín & 94 & 28 & 83 & 52 & 15 & 46 \\
\hline
\end{tabular}

*) Housing expenditures include rent + utilities (mortgage payment + utilities in the case of flat ownership). Costs of utilities were estimated at $20 \mathrm{CZK}$ per $\mathrm{m}^{2}$ monthly.

**) The highest possible regulated rent in each region was considered, which refers to the situation in the biggest cities in respective regions. In reality, average regulated rents in regions outside Prague were slightly smaller than in the table, due to lower rents in smaller cities.

${ }^{* * *}$ ) Loans from a building savings bank under the following conditions: $50 \%$ down payment is already saved and deposited in the bank account, monthly payment is set up at $0.14 \%$ of the borrowed amount, the loan is to be paid back within 10 years, state subsidy applied, no tax deductions applied.

Source: [Šetření... 1996, "Vyhláška..." 1993, Statistika... 1997].

Two remarkable differences between rental sectors with regulated and free-market rents are obvious. The first is that while the level of housing expenditures (in relation to incomes) in flats with market rents vary highly from region to region, there were almost no regional differences in the cost of living in flats with regulated rents. The second is that housing expenditures in flats with market rents were much higher than in flats with regulated rents. Living in a flat with a market rent could mean paying twice as much (Ostrava region) or even six times more (Prague) than when living in a flat of the same size and quality with regulated rent. Moreover, the high housing expenditures of average households living in rental flats with free market rent radically reduce the chances of saving money from their budget and avoiding paying high rents by buying their own flat.

Why do households simply not borrow money from banks, and then pay monthly instalments, particularly when the figures in the table suggest that it could even be cheaper than renting on the free market? There are several serious obstacles to such household behaviour. The income of many households is too low to qualify for a housing loan. The criteria of the banks usually require that, after payment of the monthly mortgage instalment and all other debts, there is at least a 1.5 multiple of the living minimum remaining at the disposal of the household applying. Provided that the household applying consists of two adults with one child under than 6 years old, the 1.5 multiple of the 
living minimum equalled 7875 CZK per month (in January 1st 1997). The bottom quarter of households in the income hierarchy, however, had no such income at that time [Príjmový... 1998], and were automatically excluded from taking out any loan for housing. The households with a median income would be able to afford a loan of about $300,000 \mathrm{CZK}$ (if they had another 300,000 CZK already saved for down payment). Together $(600,000 \mathrm{CZK})$ it could be enough to buy a large luxury flat in some regions (Ústí nad Labem, Ostrava...), a reasonably large flat in most other regions, but only a very small flat in Prague. The problem is that among households with housing needs, young couples with a child or children are heavily over-represented. Such households, however, usually rank among the poorer ones [Večerník 1997]. Moreover, many potential loan holders simply do not have enough money saved to pay the down payment.

The last but by no means the least obstacle to receiving a loan is the problem of debt guarantee. To be sure that the loans are secure, banks require a debt guarantee from applicants, the value of which must be at least about $25 \%$ higher than the amount of the intended loan. Such a guarantee could be savings, shares or other valuables, or - most commonly - real estate (flats, houses, building lots). But practically none of the applicants seeking housing have either of the above mentioned possibilities. If they had, they would not have housing problems, but would simply buy a flat without any loans. The critical point is that applicants cannot offer as a guarantee the flat they intend to buy using the borrowed money, because they do not possess it at the time their application is processed. There is a theoretical possibility that the seller will be willing to wait for the money: just selling the flat after gaining part of the money, transferring legal ownership rights to the buyer, letting the buyer go through the loan procedure, and then receiving the rest of the money afterwards. In practice, however, almost no seller is willing to sell a flat this way, as it is a risky procedure, which could take several months to be completed. Buyers, on the other hands, are in a tricky position: They cannot borrow money before buying a flat, and they cannot buy a flat before borrowing the money. Thus the only applicable solution remains to persuade friends, parents or other relatives (if any have valuable property) to offer their real estate as a guarantee for the bank. This condition apparently further reduces the number of qualified applicants, as such guarantors may be hard to find.

\section{Conclusions}

The housing market in the post-communist Czech Republic is not a single market with uniform rules of operation, but rather a mosaic consisting of different sectors and regional sub-markets that to a high extent function autonomously. No matter how it has come about that different households have found themselves in a different part of the 'mosaic', their housing situation must be taken into account when thinking about social inequalities. It is evident that the position of the households in the housing market does not simply reflect the differences in household incomes. The relation between housing inequalities and social inequalities is complex. In many cases, the housing situation of households is directly influenced by property value, the structure of incomes, and expenditures. Thus the differences in housing may also be an important source of social inequalities in general.

The way the housing market has developed in the course of the economic transformation favoured some groups while disfavouring others. The regionally unequal increase of prices benefited the owners of real state located in the areas evaluated by the 
market as the most attractive (Prague and its surroundings, regions of Brno, Plzeň, Zlín...). On the other hand, those who owned real estate in the least attractive regions (North-Western Bohemia, Ostrava region...) were relatively disadvantaged. As far as the division of the housing market into segments is concerned, the 'winners' were private flat owners, members of housing co-operatives, and those who had a chance to buy a municipal flat for prices below the market price. The relative 'losers' were those who found themselves in the position of tenant in privately owned houses. But the most apparent 'losers' were those who simply had no flat to live in, and were pressed to rent a flat out of the free market, particularly in more expensive regions. They not only had to pay substantially more for the same as what others are paying for, but furthermore, they were often not considered as being poor, as state social policies are based on income testing (the poor are those who have a low income), and do not take into consideration the housing situation.

Finally, it should be taken into account that 'winners' and 'losers' are to some extent relative categories. As the laws and other rules regulating the housing market change rather frequently, the situation of different groups can also change substantially. Even the development in the housing market, which is driven by 'pure market forces', is far from stable, and what may look like an advantage at one time may not be advantage later. Regardless of the scope of uncertainty connected with the development of the housing market, we believe that any attempt to incorporate the problems of housing into the research of the development of the social structure is worthwhile.

TOMÁŠ KOSTELECKÝ was a researcher in the Institute of Sociology of the Czech Academy of Science from 1993 to the middle of 2000. In summer 2000 he joined the Gallup Organization Czech Republic, where he serves as a research director. His main scientific interest lies in the areas of political geography, housing and the social consequences of transformation.

\section{References}

Andrle, A. 1994. "Př́tomnost a budoucnost bytové výstavby v ČR [The Present and Future of Housing in the Czech Republic]." S'94 41: 8-9.

Andrle, A., J. Vlášek 1998. "Bytová výstavba 1988-1997 [Housing 1988-1997]." Veřejná správa'98 31: I-XII.

Castels, M. 1977. The Urban Question: A Marxist Approach. London: Matthew Arnold.

Dunleavy, P. 1981. Politics of Mass Housing in Britain 1945-1975: A Study of Corporate Power, and Professional Influence in the Welfare State. Oxford: Clarendon Press.

Heřmanová, E., T. Kostelecký 2000. "Regionální diferenciace na trhu bydlení a její př̌ičiny [Regional Differentiation of the Housing Market and its Causes]." Sociologický časopis 36: 41-56.

Kemeny, J. 1992. Housing and Social Theory. London: Routledge.

Kostelecký, T. 1994. "Regionální diferenciace sociálních problémů v České republice [Regional Variability of Social Problems in the Czech Republic]." Working Papers 94:5. Praha: Sociologický ústav AV ČR.

Kostelecký, T. 1995. "Rozdíly v chování regionálních populací a jejich příčiny [Differences in the Behaviour of Regional Populations and their Causes]." Working Papers 95:5. Praha: Sociologický ústav AV ČR.

Machonin, P., M. Tuček et al. 1996. Česká společnost v transformaci [Czech Society in Transformation]. Praha: Sociologické nakladatelství. 
Matějů, P. 1993. "From Equality to Equity. The Czech Republic Between Two Ideologies of Distributive Justice." Czech Sociological Review 1: 251-276.

Matyáś, F. 1994. "Průzkum bytové situace [Housing Situation Survey]." Pp. 74-78 in Aktuální otázky bytové politiky, ed. by A. Andrle and J. Wagner. Praha: Terplan.

Př́jimový mikrocensus 1996 [Income Microcensus 1996]. 1998. Praha: Český statistický úřad.

Rex, J., R. Moore 1967. Race, Community and Conflict. Oxford: Oxford University Press.

Saunders, P. 1978. "Domestic Property and Social Class." International Journal of Urban and Regional Studies 2: 233-251.

Siksiö, O., L. E. Borgegard 1990. "Markets in Distress - On Access to Housing in Local Housing Markets.” Pp. 149-175 in Housing Sociology in Times of Change, ed. by O. Siksiö. Stockholm: The National Swedish Institute for Building Research.

Statistika rodinných účtů 1996 [Family Expenditures Survey 1996]. 1997. Praha: Český statistický úr̆ad.

Šetření cen na trhu s bydlením [Housing market prices survey]. 1996. Praha: Sociologický ústav AV ČR.

Vajdová, Z., L. Buštíková 1998. "Lidé na trhu s bydlením [People in the Housing Market]." Data \& Fakta, no. 8 .

Večerník, J. 1992. "Změny v př́ijmové nerovnosti v letech 1988-1992 [Changes in Income Distribution in 1988-1992]." Sociologický časopis 28: 666-684.

Večerník, J. 1997. Markets and People. The Czech Reform Experience in a Comparative Perspective. Aldershot: Avebury.

"Vyhláška ministerstva financí o nájemném z bytu a úhradě za plnění poskytovaná s užíváním bytu." 1993. Sbirka zákonů č. 176/1993. Praha: Vydavatelství a nakladatelství MV ČR. 